\title{
Geological Hazards Occurred on the Road Connecting Vashlijvari-Lisi (M. Machavariani Street) in Tbilisi
}

\author{
Merab Gaprindashvili1,2 \\ ${ }^{1}$ Department of Geology, National Environmental Agency, Tbilisi, Georgia \\ ${ }^{2} \mathrm{PhD}$ Student of Mining Geological Faculty, Georgian Technical University, Tbilisi, Georgia \\ Email: gaprinda13@yahoo.com
}

How to cite this paper: Gaprindashvili, M. (2021). Geological Hazards Occurred on the Road Connecting Vashlijvari-Lisi (M. Machavariani Street) in Tbilisi. Journal of Geoscience and Environment Protection, 9, 15-27. https://doi.org/10.4236/gep.2021.911002

Received: September 30, 2021

Accepted: November 7, 2021

Published: November 10, 2021

Copyright $\odot 2021$ by author(s) and Scientific Research Publishing Inc. This work is licensed under the Creative Commons Attribution-NonCommercial International License (CC BY-NC 4.0). http://creativecommons.org/licenses/by-nc/4.0/

\section{Open Access}

\begin{abstract}
The capital of Georgia-Tbilisi has a very convenient location and is a node of the transit corridor. Along with natural-geological conditions, its complexity is due to the rapid demographic growth of the city in a highly "sensitive" area of the geological environment and the pressure of high engineering and agricultural activities. In Tbilisi, it is observed almost all types of geological hazards, including landslide-gravitational, suffosion, debris/mudflows, river bank erosion and inundation were caused by groundwater. These hazards cause high damages to the residential houses and other infrastructure facilities. Most importantly and most tragically is that these kind of negative geological events are often accompanied by human casualties. The study discusses the geological processes developed in March 2021 in the corridor of the Vashlijvari-Lisi road (Machavariani Street). The information obtained from the study, reflects the triggering factors of the geological hazards, also damages caused by them, and provides recommendations for short-term and long-term protective measures that should ensure the sustainable operation of the road and other infrastructure facilities.
\end{abstract}

\section{Keywords}

Landslide, Geology, Tbilisi, Geological Hazard, Disaster, Georgia

\section{Introduction and Study Area}

Study area situated in the capital of Georgia, Tbilisi, on the right bank of Mtkvari valley, on the southern slope of the sub-lateral extended and flattened Lisi ridge, with south-eastern direction. Georgia hosts a great variety of morphological and climate conditions from the humid, subtropical coastlines to highland-alpine-nival 
areas; whenever natural disasters strike the country, this usually leads to a great number of casualties, also due to very populated human settlements all across Georgia (Tsereteli et al., 2014; Gaprindashvili et al., 2014; Gaprindashvili \& Westen, 2016; Gaprindashvili et al., 2018, Gaprindashvili et al., 2021).

At present, under the conditions of increased demand on constructions, the territory of Georgia and its capital-Tbilisi city is being developed under the most complex geological conditions, which is frequently accompanied by widespread occurrence and activation of hazardous geological processes, such as landslide-gravitational and suffosion, inundation caused by groundwater, debris and mudflows, often triggered by heavy rainfall, also extreme complications of geo-ecological situation (Gaprindashvili et al., 2019; Tsereteli et al., 2019; Gaprindashvili et al., 2016; Gaprindashvili \& Westen, 2016; Department of Geology 2019; Gadrani \& Gaprindashvili, 2017).

Study area, which includes Vashlijvari-Lisi road section (M. Machavariani Street) on both sides, is bordered by temporarily cut V-shaped ravines. At the top, surface of the watershed is covered with grass and deciduous shrubs. The slope inclination varies slightly from $10^{\circ}$ to $15^{\circ}$, and from the slope to the river, in the direction of Mtkvari river, the natural surface is artificially (technogenically) strongly transformed by the ongoing road construction activities and is characterized by sharply variable inclination (Figure 1).

\section{Geology and Hydrogeology}

The slope is geologically built of rocky, semi-rocky and clayey rocks of the $\mathrm{Pa}$ leogene system, middle and upper sub-floors of the Oligocene $\left(\mathrm{E}_{3}^{2+3}\right)$, which are arranged according to natural and numerous artificial strips (semi-excavated slopes), and medium-layered sandstones in turn, with thin-layered sandstones with interlayer of clays and aleurolites (Gaprindashvili et al., 2019).

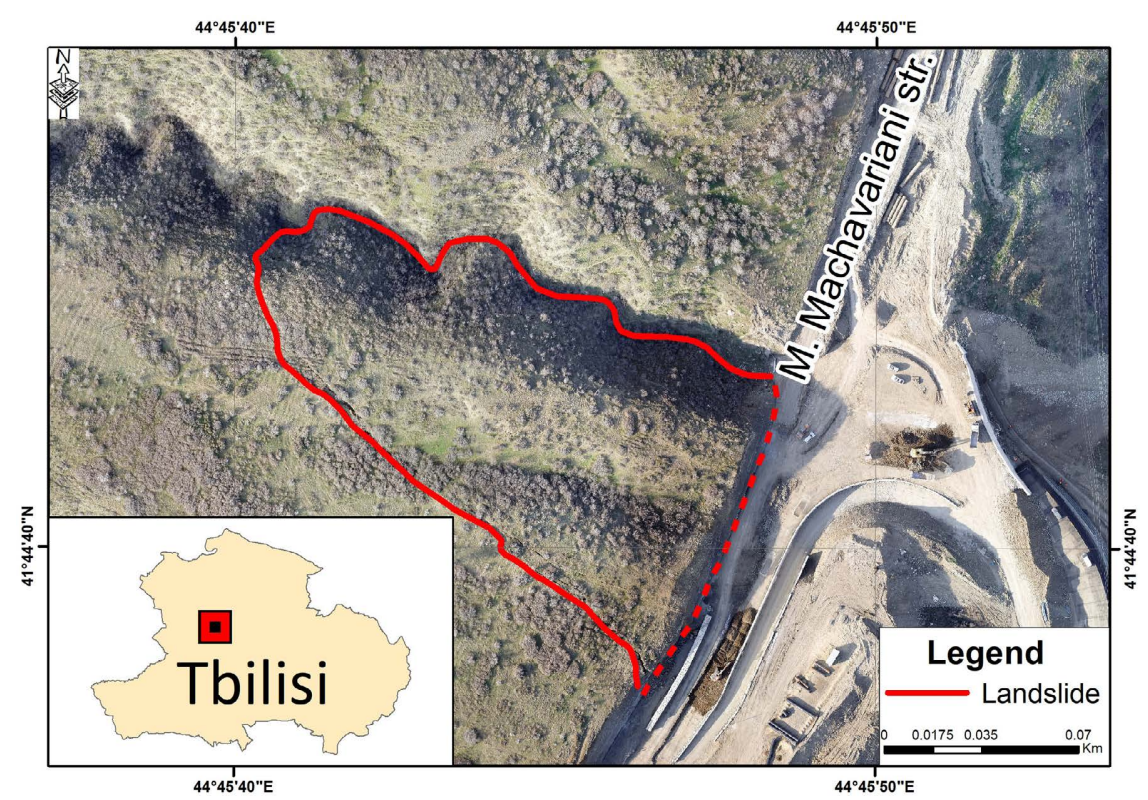

Figure 1. Study area. 
The sandstones are gray and greenish-gray, characterized by heterogeneous granularity and vary in array from fine-grained to coarse-grained and sometimes gravelly. The sedimentary material of sandstones is limestone and clayey-limestone, but the mass is dominated by tuffogenic material, which is represented by the products of washing and sedimentation of rocks of the Middle Eocene $\left(E_{2}^{2}\right)$ (Gaprindashvili et al., 2019).

Aleurolite in the weathered zone are gray, black, and yellowish-gray. They are usually pure grain. The clays are non-carbonate, yellowish-brown, sometimes leafy. The inclination of the slope and the planes of layers of its bearing rocks are almost coincidental, while the dip direction of the rocks varies in a slight range (from $15^{\circ}$ to $20^{\circ}$ ).

During the assessment of the study and surrounding areas, groundwater discharges were observed only in one of the cracks formed in the last days, but it is not excluded that during seasonal and heavy rains, precipitation may occur (infiltration) in intensively cracked-depleted, temporary formation of water solutions and violation of their regime. In addition, we do not rule out the presence of groundwater in the so-called landslide bodies described below, in the sliding surface zone, at a depth of $12-14$ meters.

\section{Morphology}

Morphologically, study area is located at the point of contact of two adjacent morphological districts, namely: the first area belongs to the sub-latitudically folded Lisi anticline ridge structured by Middle Eocene Tufogenic, Upper Eocene and Lower Oligocene sandy-clay deposits developed by Lower mountain Plateau-like technomorphic relief type, which is characterized by high degree of erosive separations, variable intensity area erosion and wind erosion processes. The second area belongs to the type of erosive-denudative low-terrestrial relief of the right terraced valley of the Mtkvari River valley developed on the substrate of sub-latitudically folded middle and upper Oligocene sandstone-clay sediments. It should be emphasized that in the conditions of disturbance of the natural balance of the slopes, both districts are characterized by secondary reactivation of the old (historical) landslide bodies, as well as activation of the debris/mudflows and ravine-type discharge process during the seasonal and torrential rains (Figure 2, Figure 3).

\section{Tectonics and Seismicity}

According to the map of tectonic divisions of the territory of Georgia (Gamkrelidze, 2004), the target area belongs to the Lesser Caucasus fold system, Adjara-Trialeti (fold-anticlinorine) zone, the southern sub-zone of Aspindza-Tbilisi, and is located to the east end. On the washed southern slope of the sub-folded Lisi anticline, which is complicated by faults of different order and direction (tectonic and exogenous). According to the scheme of seismic zones of the territory of Georgia, the target area belongs to the 8-magnitude earthquake zone. 


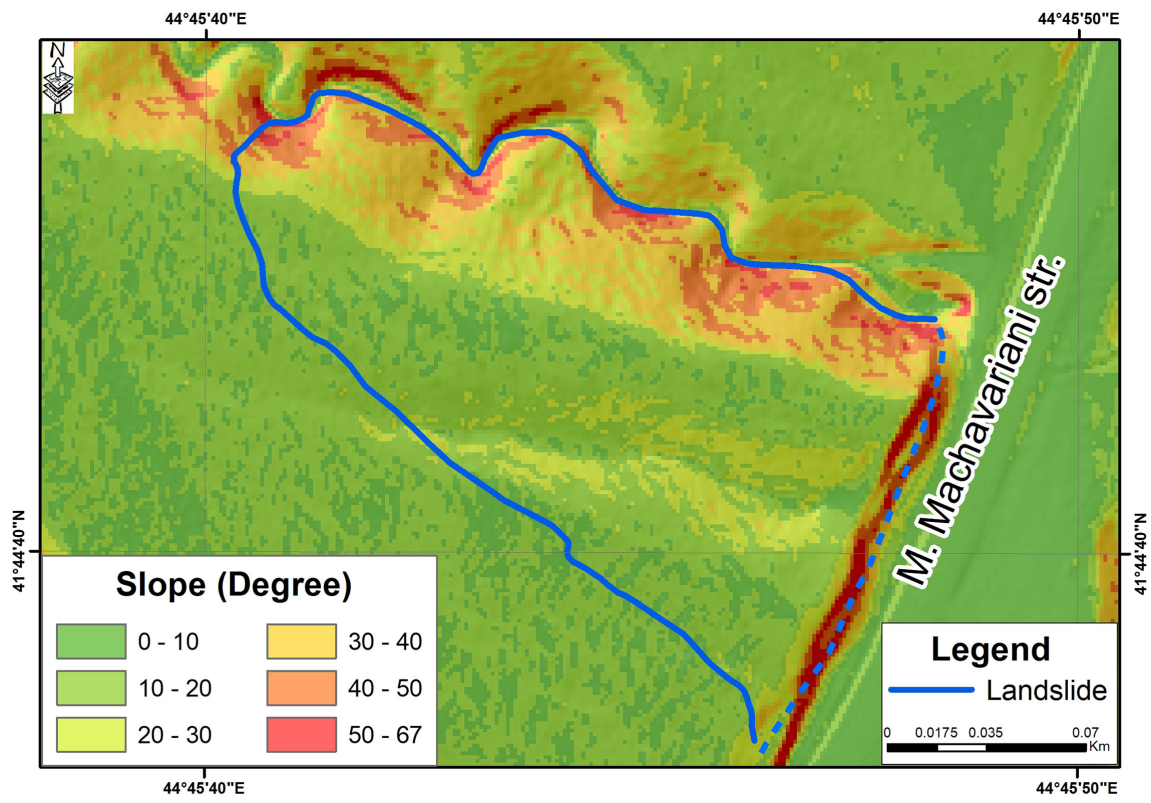

Figure 2. Slope map of study area.

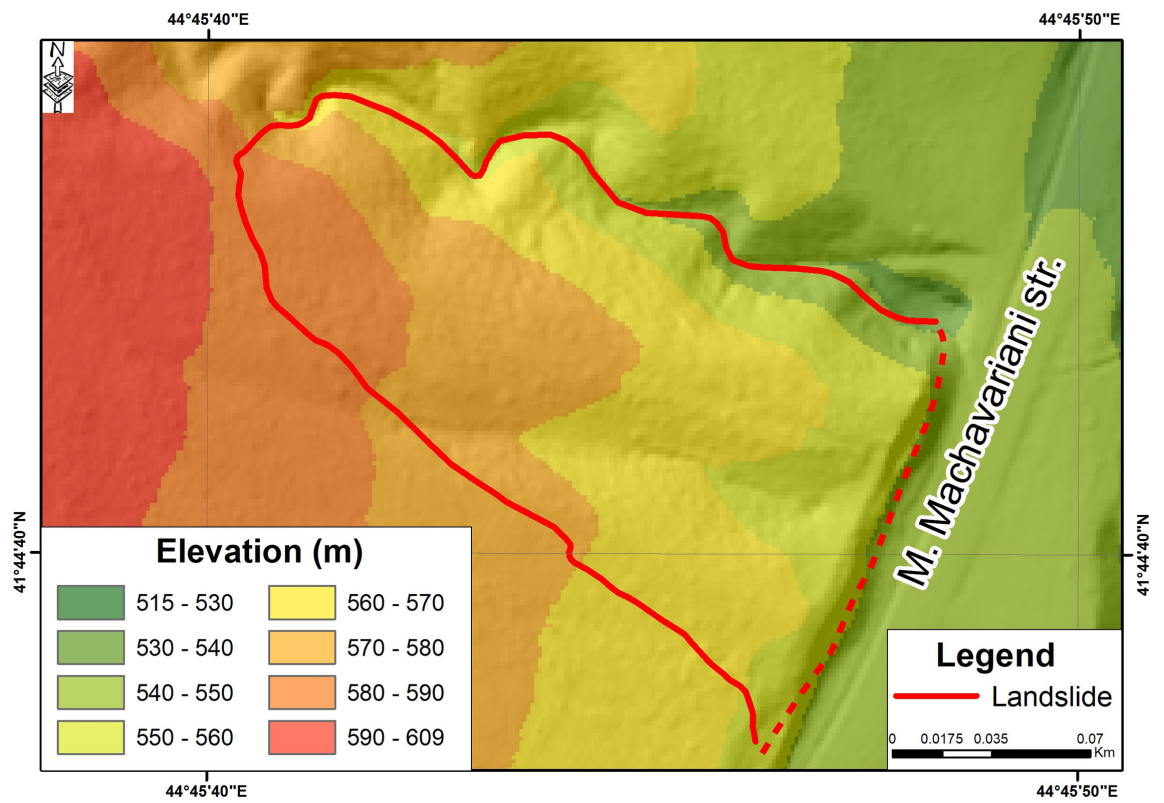

Figure 3. Elevation map of study area.

\section{Results and Discussion-Geological Hazards}

On March 1, 2021, in the north-eastern part of the local watershed on the right side of the Vashlijvari-Lisi road, in the area of the old landslide (historical) block of tectoseismogenic genesis, which is in the phase of temporary stabilization, a secondary generation block-slide type landslide was developed (area $1.57 \mathrm{ha}$ ). In order to produce instrumental observations on the nature and dynamics of the subsequent deformation of the formed landslide body, the construction company operatively arranged 11 cross-sections in the form of GPS points placed in a strip along the landslide body (Figure 4). 
Based on visual and measurement studies of landslide dynamics from 1 to 17 March, a number of cases of regressive expansion of the landslide body at the expense of capturing surrounding areas have been identified, as a result of which most of the observer GPS points are deformed or already within the landslide body (Figure 5). The probable depth of the landslide body is in the range of 12 $14 \mathrm{~m}$, taking into account the morphological and geological conditions of the area, as well as the existing deformations.

As of March 17, 2021, in the north-eastern part of the watershed, a tendency of formation of local bodies with vectors of different displacements was observed, and the whole landslide body can be considered conditionally in 2 areas:

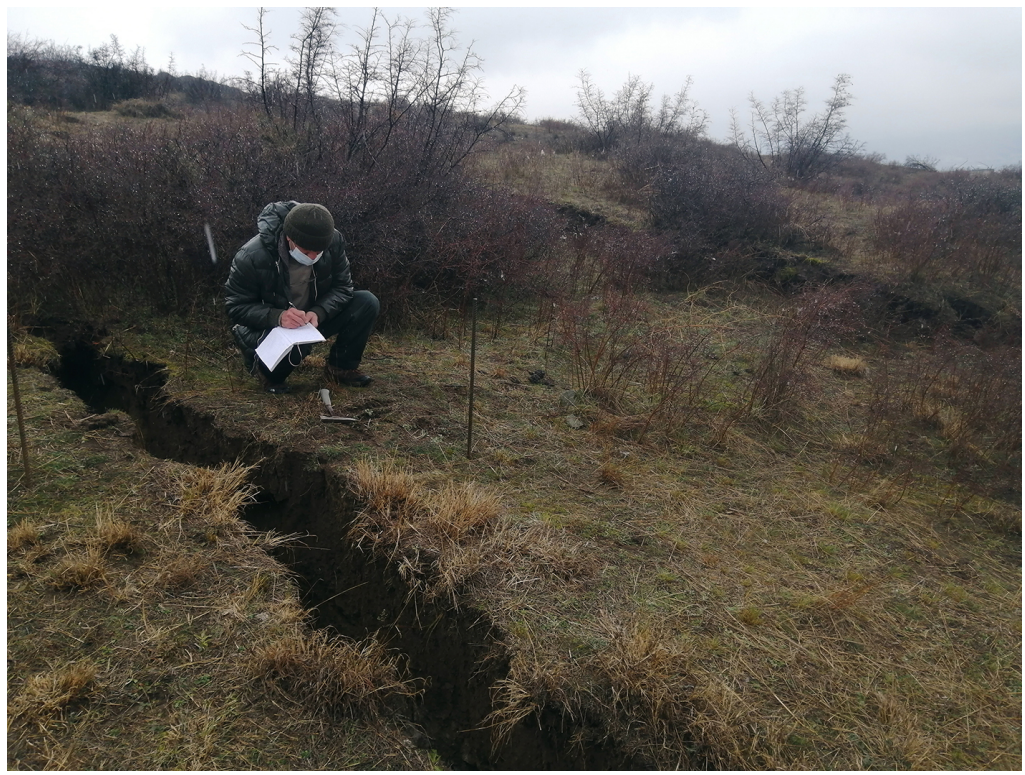

Figure 4. Monitoring rappers (GPS) arranged on a landslide crack.

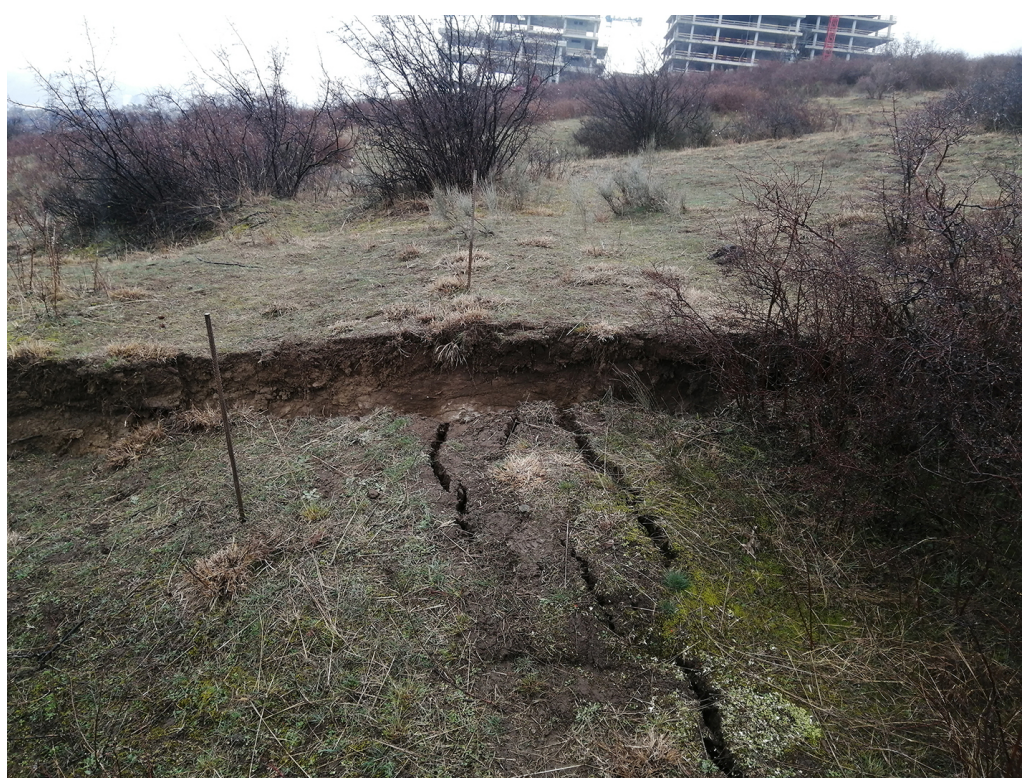

Figure 5. Monitoring rappers (GPS) arranged on a landslide crack. 
Landslide 1 is developed in the contour of a local catchment with a weakly concave surface in the watershed series. The exposure of the landslide body is south-eastern. Its surface is covered with grass and deciduous shrubs. The slope of the surface varies from $10^{\circ}-15^{\circ}$, while the inclination of the end of the slope (along the road section) ranges from $75^{\circ}-80^{\circ}$. Landslide body developed to the local catchment of a dry ravine contour is wedge-shaped in plan and is defined by landslide ditches and cracks with variable width and amplitude along the boards. The width of the trench formed at the foot of the body along the right board varies from 1.99 to $2.485 \mathrm{~m}$, and the visible depth from 1.33 to $3.7 \mathrm{~m}$ (Figure 6).

However, it should be noted, that the base of the trench is partially filled with debris and its actual depth is much greater. The deformation of the landslide body in the direction of the head is expressed in the form of cracks, which narrows up to $2-3 \mathrm{~cm}$ in a separate section in the upward direction, and in some places is transformed into zones of parallel cracking (Figure 7, Figure 8). The width of these zones reaches $5-6.5 \mathrm{~m}$, while the visible depth varies from 2.78 $2.87 \mathrm{~m}$ to $4.5-6.6 \mathrm{~m}$ (Figure 9).

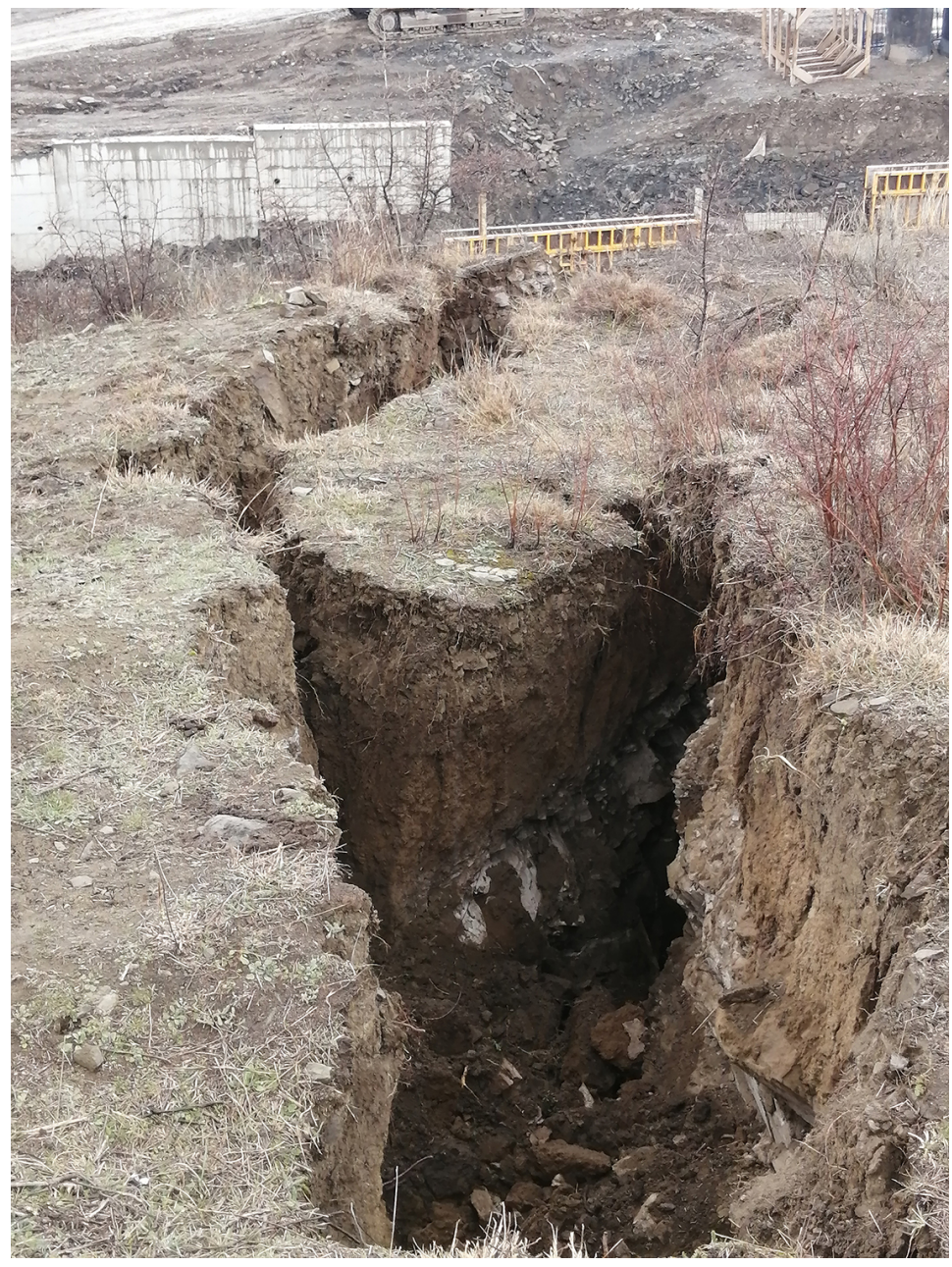

Figure 6. Landslide cracks near the landslide scarp. 


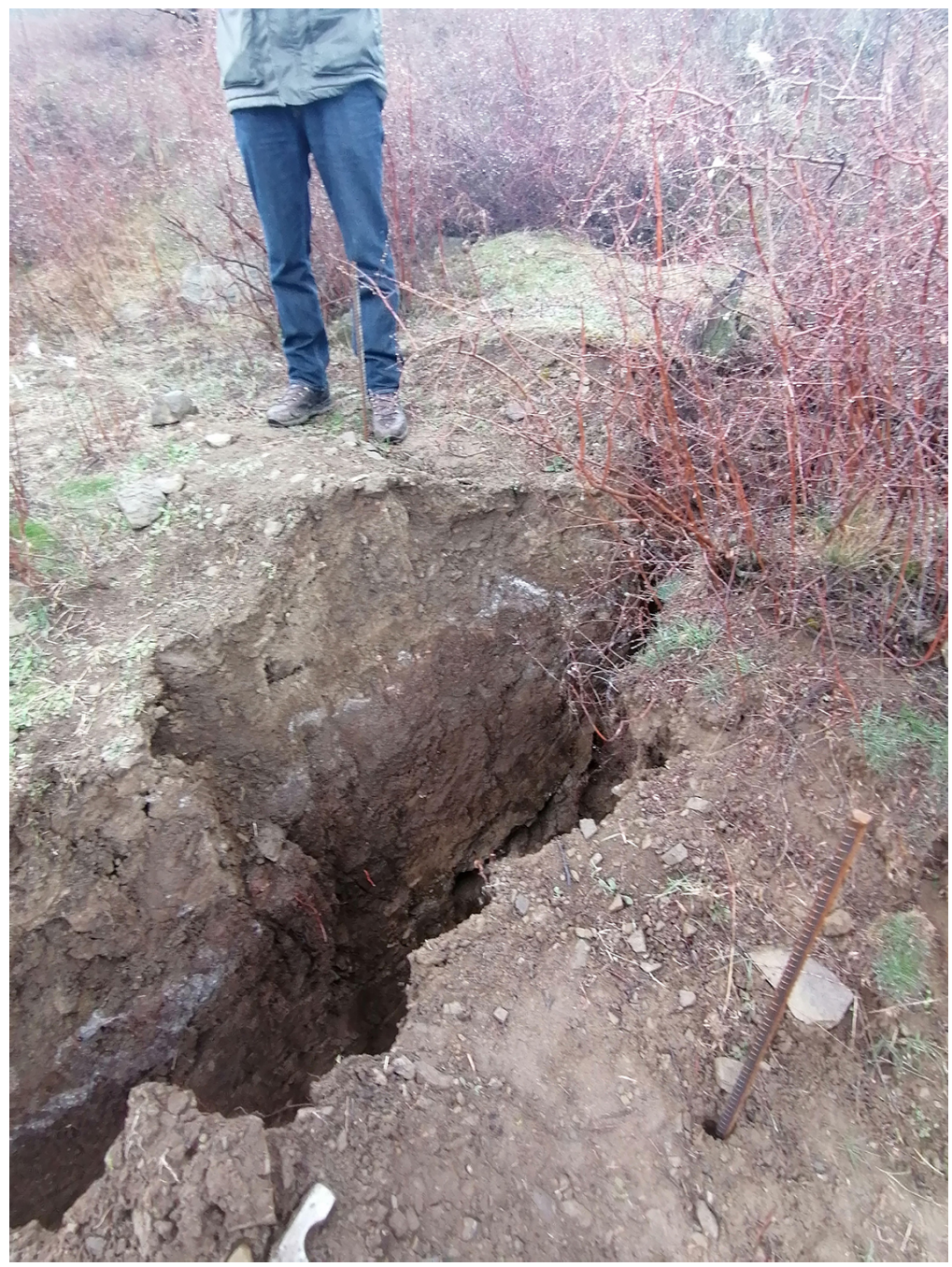

Figure 7. Landslide cracks near the landslide scarp.

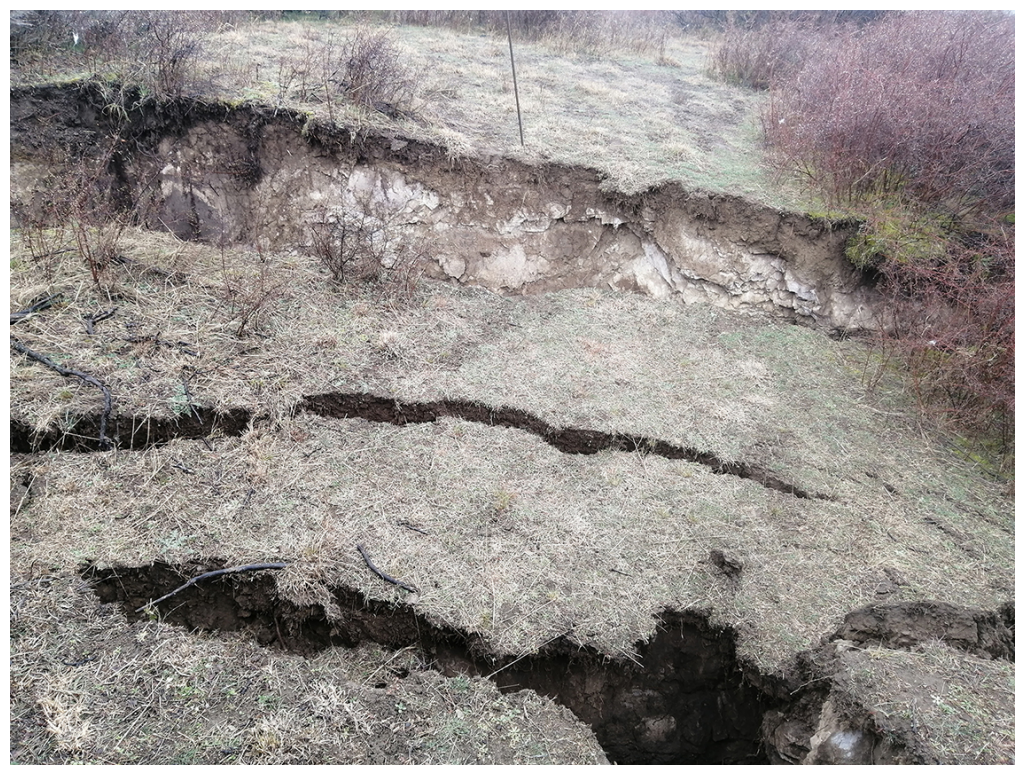

Figure 8. Zones of parallel cracking. 


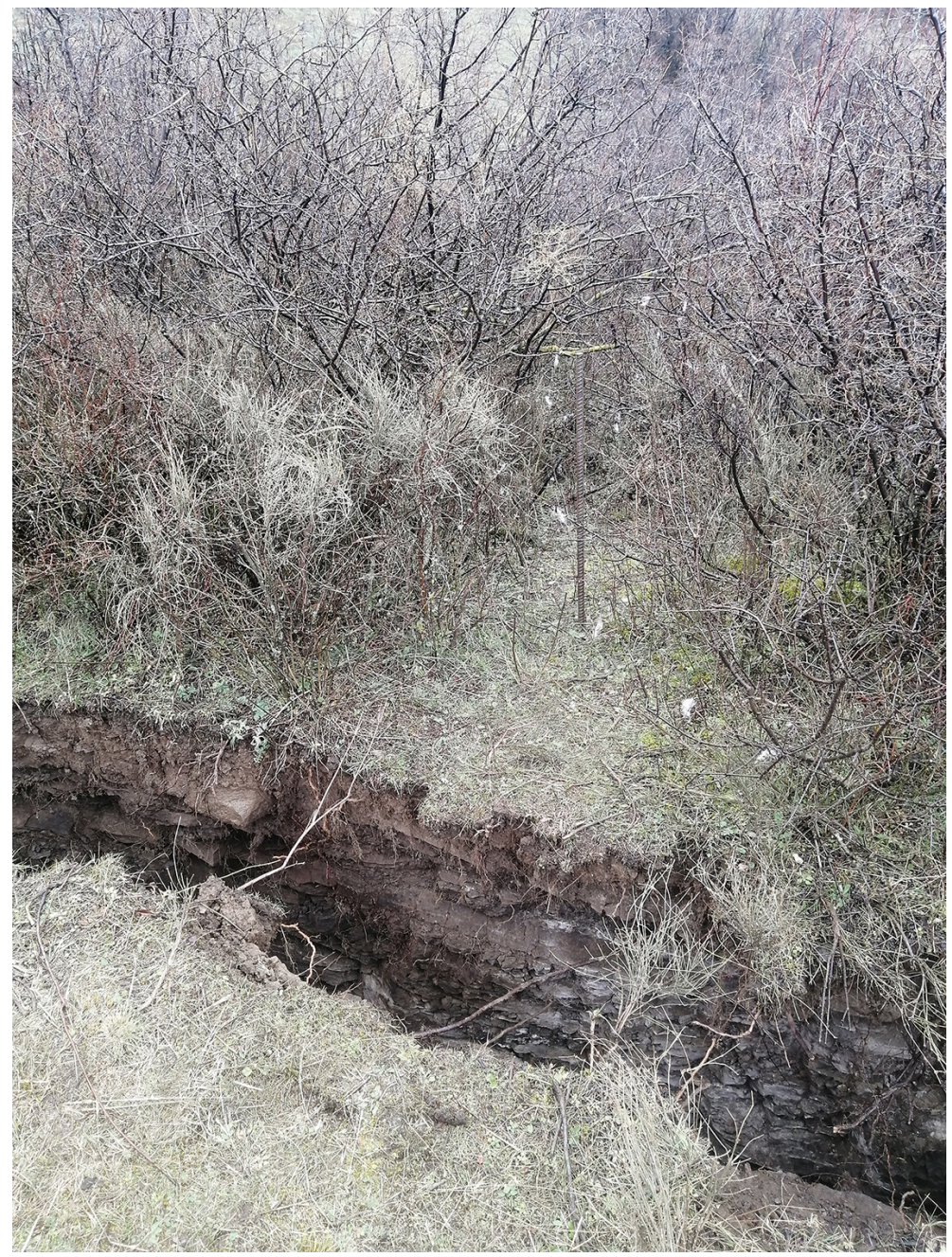

Figure 9. Zones of parallel cracking.

In the direction of the head between the cracks bordering the two boards, the distance gradually narrows and at the head, the cracks smooth out and merge with each other. It is noteworthy that during the assessment period the landslide body was characterized by regressive expansion both in the south-west and north-east directions. During the observation period, the velocities of the body move south-east, south-east along the right board at the foot, and north-east to the direction of left board.

The 1st landslide area is wedge-shaped in the plan. Its length on the slope is $164 \mathrm{~m}$, the base of which is connected to the surface of the semi-excavated slope with an inclination of $75^{\circ}-80^{\circ}$. According to the deformation in the slope contour, the depth of the landslide body as of March 17 ranges from $5-6 \mathrm{~m}$, and it should be emphasized that signs of new deformation were observed below the plane of the landslide. Slope bearing in the form of subvertically cracked rocks and subdivided into blocks, as well as chaotic cracking of the sediment-type fault line (Figure 10). Also in the strip along the water pipeline shelf, in the form of compacted ground compaction, which is most likely an indication of the forma- 
tion of a much larger capacity of the landslide body and the apparently invisible to us probably new activation in the depth (Figure 11). From the north 1st landslide area is bordered by the 2 nd landslide area.

The 2nd landslide area is developed on the right side of the unnamed ravine, with a north-eastern exposure, at the head of the slope, and after a sharp turn from the ridge zone, on a steeply sloping catchment slope. The landslide body spatially includes the ridge of the watershed series and the contour of a steeply sloping local watershed. The landslide body at the head is defined by a crack up to $1.2-1.2 \mathrm{~m}$ wide and $4-11.0 \mathrm{~m}$ deep (Figure 12 ).

The crack extends northeast to the bed of the unnamed ravine and forms the boundary of the left board of the landslide body. The width of the crack along the board decreases to $1.3-0.2 \mathrm{~m}$ and the depth to $3.2-0.5 \mathrm{~m}$.

From the south-east, the border of the right board is a shallow arc-shaped crack, the developmental signs of which are not currently observed. The vector of motion of the landslide body developed in the ridge and in the contour of the catchment slope is north-eastern.

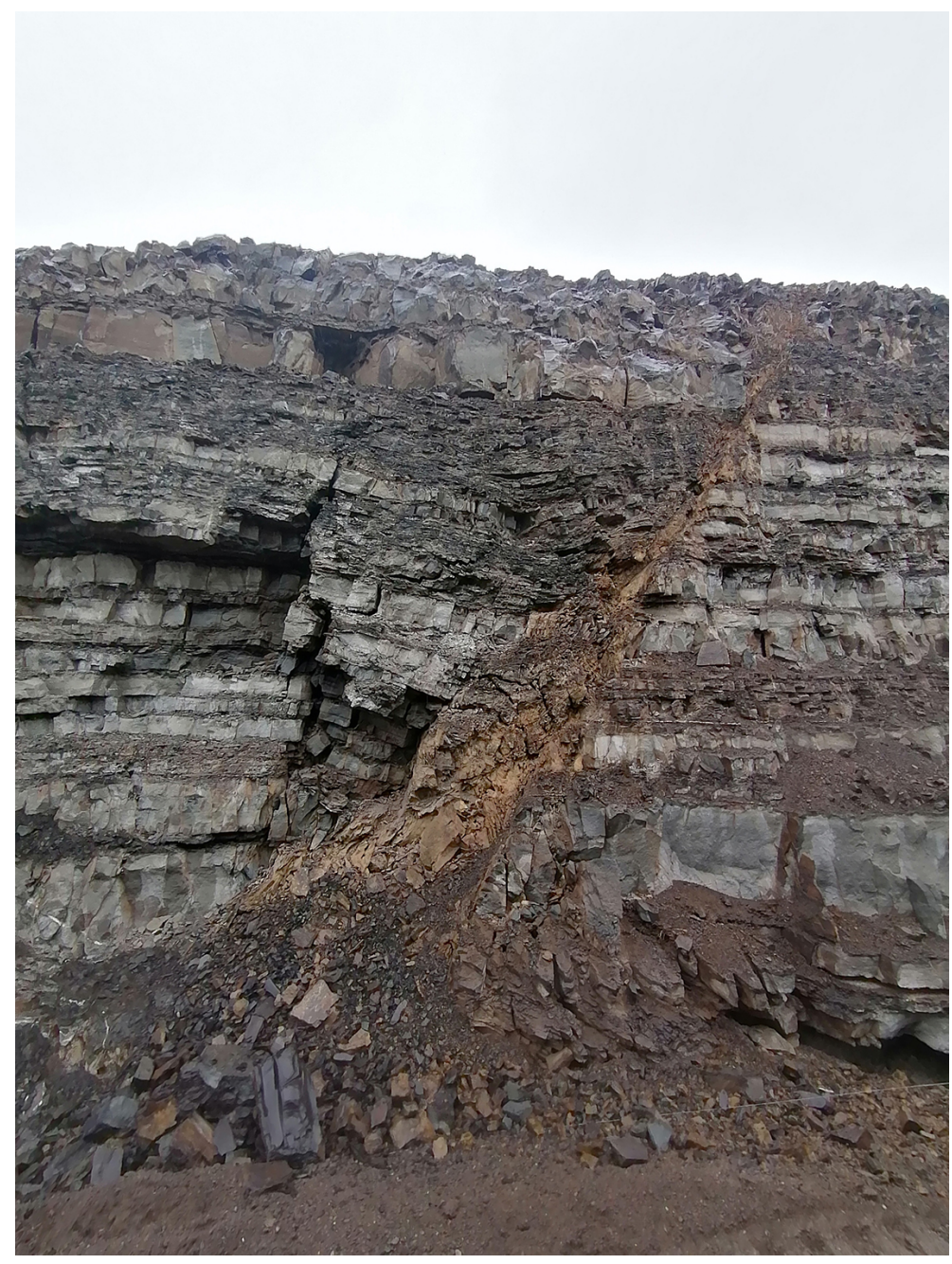

Figure 10. Historic tectonic fault line. 


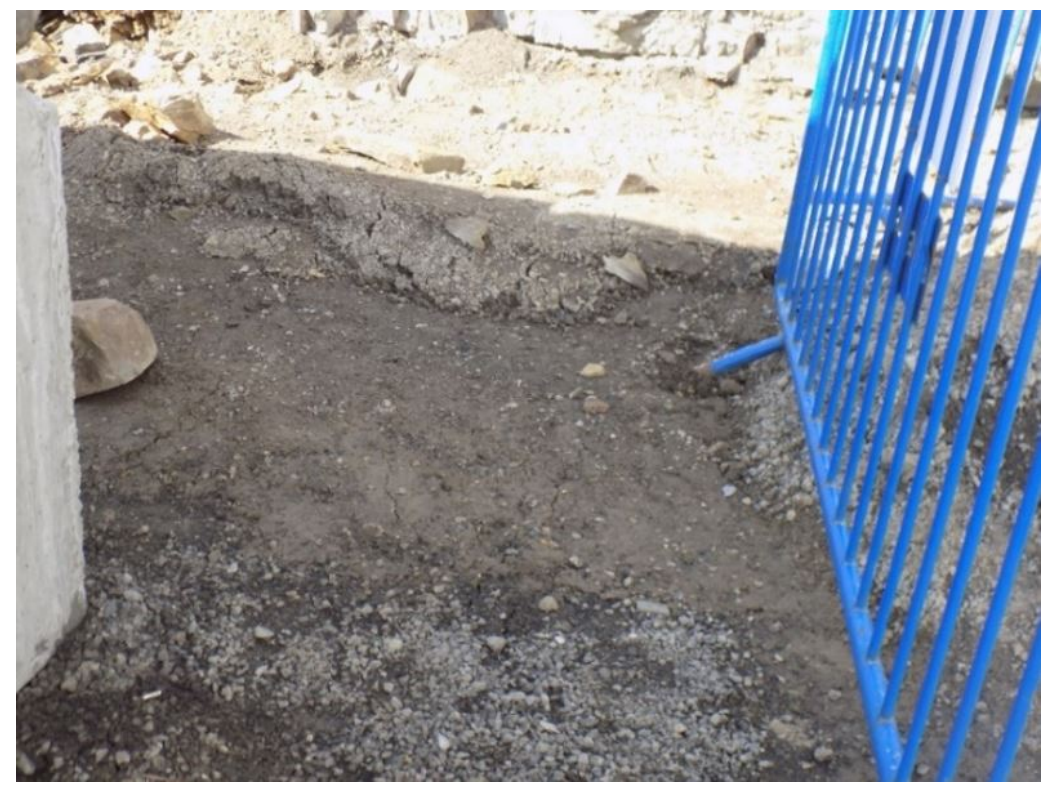

Figure 11. Lifting near the landslide tongue.

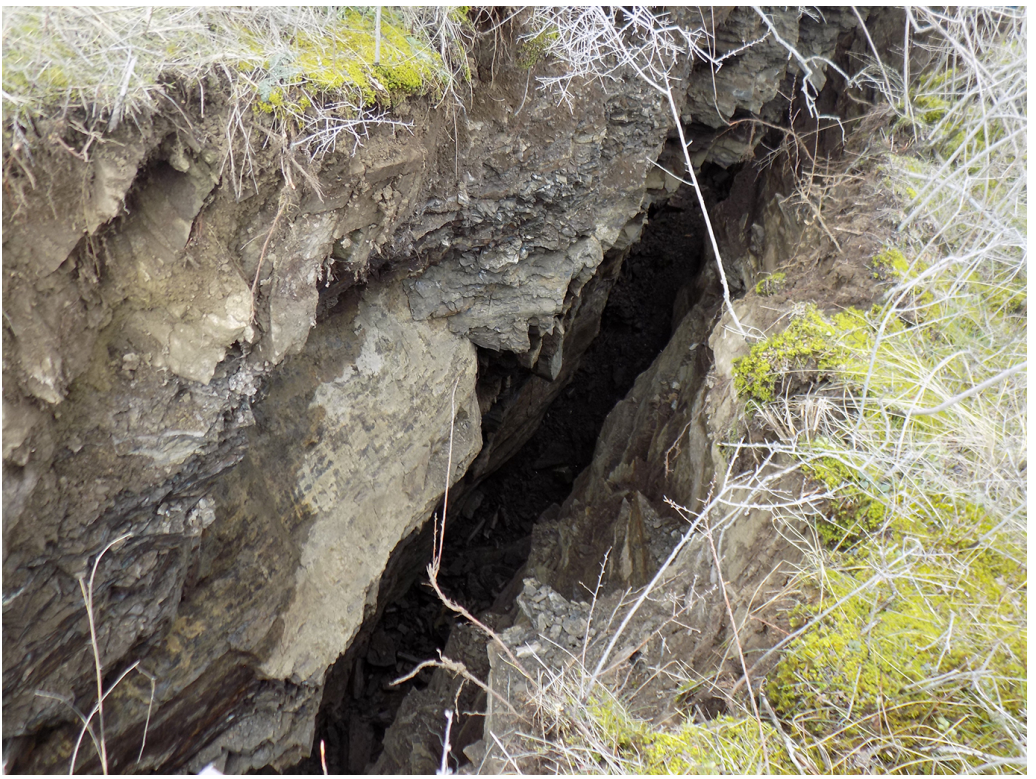

Figure 12. Landslide crack at the head of the 2nd landslide area.

The 2nd landslide area is bordered on the south-east side by a narrow sub-latitudical watershed, with a local catchment slope. The exposure of the catchment slope is northeastern, while the slope of its surface is heterogeneous and varies from steep to strongly steep. The catchment slope base is connected to the bed of the same unnamed ravine. In the north-eastern part of the catchment slope, signs of surface deformation are observed in the form of narrow and shallow crack, which extends from the ravine bed to the top of the local watershed and then to the south-east to the foot of the ravine. The formation of such deformations in the catchment slope and local watershed area is likely to represent the development of a landslide body in the early stages of formation. 


\section{Triggering Factors and Negative Consequences}

1) Causes:

On the right side of the road connecting Vashlijvari-Lisi (Mukhran Machavariani Street), activation of landslides in the north-eastern part of the south-eastern watershed must be caused by the combined impact of the following natural and man-made factors, namely:

- Morphological features of the study and surrounding areas, in particular the existence of a landslide block of ancient (historical) tecto-seismogenic genesis formed in the distant past;

- Due to the high degree of cracking and weathering of the rocks of the study and surrounding areas, degradation of their physical-mechanical properties, disturbance of gravitational equilibrium in the conditions of coincidence of flatness and slope inclination of the rocks and decreased susceptibility towards landslide-erosion processes;

- Tectonic conditions of the study and surrounding areas: high degree of dislocation of sedimentary rocks and intermittent disturbances of different ranks and directions;

- Due to the high cracking and weathering of the rocks of the study and surrounding areas, due to the seasonal formation of groundwater cracks formed in the zone of the erosion crust, chemical leaching of the minerals that make up the rocks;

- During the last two decades, different intensity seismic activity (earthquakes) on the territory of Tbilisi;

- Also with engineering activities and other factors carried out in different periods within the above mentioned landslide block.

2) Negative consequences caused by landslide processes:

- Part of the landslide masses moved within the highway (M. Machavariani Street);

- Deformed 3 existing water pipelines (900 $\mathrm{mm}$ in diameter) operating along the highway;

- The fiber-optic line of the Internet is out of order;

- The movement of vehicles on the highway was restricted.

\section{Conclusions and Recommendations}

Given the extremely complicated geodynamic conditions of the study area, we consider it urgent to implement the following measures:

\section{1) Urgent:}

- Temporarily restrict the movement of vehicles and pedestrians on the section;

- Continuation of monitoring of the monitoring network arranged by the contractor on the landslide body;

- Arrangement of additional instrumental monitoring network (including early warning system) in the area of the landslide body, as well as in the corridor 
of the road (M. Machavariani Street) and the main pipeline;

- Removal of deformed landslide masses and their placement along the road, in the tongue part of the landslide, which will temporarily act as a protective barrier ("counterforce");

- Treading the surface of the landslide body, creating a shape of relief that will significantly reduce the energy potential of the slope;

- Filling the cracks on the landslide body with clay soils and compacting them;

- Arrangement of a circular drainage canal ("mining canal") near the head of the landslide body, beyond its contour, in relation to surface water flows, in the natural watercourses (ravines).

2) Measures needed for long term maintenance of the slope stability:

- Carrying out detailed complex surveys of the study and the surrounding area and implementing landslide protection measures according to the project based on it, in particular;

- Additional removal of deformed landslide masses;

- Bringing the terrace stairs to optimal condition;

- Arrangement of retaining walls and anchors in several rows (at least 2) on landslide body (these measures should be decided based on detailed studies);

- Continuous regulation of surface and groundwater;

- Uninstallation of a temporary barrier created by landslide masses in the tongue part of the landslide body;

- Continue instrumental monitoring in and around the landslide body contour.

\section{Acknowledgements}

The author would like to thank Department of Geology of National Environmental Agency of Georgia providing various datasets used in this study.

\section{Conflicts of Interest}

The author declares no conflicts of interest regarding the publication of this paper.

\section{References}

Department of Geology, National Environmental Agency of Georgia (NEA) (2019). Information Geological Bulletins (2000-2019). National Environmental Agency of Georgia.

Gadrani, L., \& Gaprindashvili, G. (2017). Modern Geo-Ecological Conditions and Terrain Transformation of Tbilisi (Georgia). Landscape Architecture and Regional Planning, 2, $36-42$.

Gamkrelidze, E. (2004). Scheme of Tectonic Zoning of the Territory of Georgia. State Department of Geology.

Gaprindashvili, G., \& Westen, C. V. (2016). Generation of a National Landslide Hazard and Risk Map for the Country of Georgia. Natural Hazards, 80, 69-101.

https://doi.org/10.1007/s11069-015-1958-5 
http://link.springer.com/article/10.1007/s11069-015-1958-5

Gaprindashvili, G., Gaprindashvili, M., \& Tsereteli, E. (2016). Natural Disaster in Tbilisi City (Riv. Vere Basin) in the Year 2015. International Journal of Geosciences, 7, 1074-1087. https://doi.org/10.4236/ijg.2016.79082 https://www.scirp.org/journal/paperinformation.aspx?paperid $=70622$

Gaprindashvili, G., Guo, J., Daorueang, P., Xin, T., \& Rahimy, P. (2014). A New Statistic Approach towards Landslide Hazard Risk Assessment. International Journal of Geosciences, 5, 38-49. https://doi.org/10.4236/ijg.2014.51006

Gaprindashvili, G., Tsereteli, E., \& Gaprindashvili, M. (2018). Landslide Hazard Assessment Methodology in Georgia. Proceedings of the 16th Danube-European Conference on Geotechnical Engineering, 2, 217-222. https://doi.org/10.1002/cepa.674

Gaprindashvili, M., Tsereteli, E., Gaprindashvili, G. (2019). Engineering-Geodynamic Conditions and Geological Hazard Assessment of Tbilisi City. Department of Geology, National Environmental Agency.

Gaprindashvili, M., Tsereteli, E., Gaprindashvili, G., \& Kurtsikidze, O. (2021). Landslide and Mudflow Hazard Assessment in Georgia. In F. L. Bonali, F. Pasquaré, Mariotto, \& N. Tsereteli (Eds.), Building Knowledge for Geohazard Assessment and Management in the Caucasus and other Orogenic Regions (pp. 265-279). Springer. https://doi.org/10.1007/978-94-024-2046-3 14

Tsereteli, E., Gaprindashvili, G., Gaprindashvili, M., Bolashvili, N., \& Gongadze, M. (2019). Hazard Risk of Debris/Mud Flow Events in Georgia and Methodological Approaches for Management. In A. Shakoor, \& K. Cato (Eds.), Proceedings of the IAEG/AEG Annual Meeting (Vol. 5, pp. 153-160). Springer. https://doi.org/10.1007/978-3-319-93136-4 19

Tsereteli, E., Gobejishvili, R., Gaprindashvili, M., \& Gaprindashvili, G. (2014). Challenges of Geologic Catastrophes in Georgia and Ways of Their Reduction. In G. Lollino et al. (Eds.), Engineering Geology for Society and Territory (Vol. 2, pp. 1767-1773). Springer International Publishing. https://doi.org/10.1007/978-3-319-09057-3 313 http://link.springer.com/chapter/10.1007\%2F978-3-319-09057-3 313 